\title{
Governance in the Establishment of the Agile Process of Urban Creative Industry Competitiveness
}

\author{
Florentina Ratih Wulandari*, Bambang Supriyono, Endah Setyowati \\ Faculty of Administrative Science \\ University of Brawijaya \\ Malang, Indonesia \\ *fr.wulandari@gmail.com
}

\begin{abstract}
This study aimed to explore how governance efforts were carried out for agile process forming in the development of Depok City competitive creative industry. This research method used a qualitative method with qualitative descriptive data analysis and for qualitative data collection techniques used snowball techniques. This study focusses on processes and mechanisms of the governance 'stakeholders in the agile process forming of the Depok City creative industry development which generated for competitiveness. These governance elements were the Local Council Depok City, the Depok City Government Agencies, and the Depok City Creative Industry Association. The study revealed that the formation of the agile process was constrained by aspects of adaptive policy innovation and aspects of competitiveness training mechanisms. The conclusion of this study was that the governance mechanism in the formation of agile processes to increase the competitiveness of creative industries in Depok City is still semi-technocratic. This is indicated by the coordination of the design of creative industrial development between stakeholders was executed but the agile process has not been fully formed. In the formation of dynamic capability agile process at the local level found that there was a role for local government collaborative networks can be used for dynamic collaborative agile processes local governance. The theoretical implications are the need for an accommodative policy framework theory for regulatory innovations in urban creative industries that are flexible to the dynamic diversity (actors) of creative industries.
\end{abstract}

Keywords-agile process, dynamic capability, dynamic collaborative local governance, creative industries

\section{INTRODUCTION}

Governance in regional development prior to the Covid pandemic has until now undergone a very dynamic process. The development of the economic sector in urban areas also needs adjustments to the changing situation in the dynamic environment. One of the reasons for this is to increase regional income. This urban area income is important to finance the running of government services and urban development efforts.

Even in Indonesia as a developing country, in urban development, it positions the city as a growing point that stimulates the trickledown effect of its surrounding areas, where the acceleration of urban development to create a city that is liveable, safe, and comfortable, green that resists climate and disasters, is smart and has city competitiveness [1]. Several cities that support the growth poles play an important role in the spill over urban development and trickledown effect of the surrounding area. For the growth pole in Indonesia, Jakarta is the main city that influences the surrounding satellite cities which also act as a hinterland, including Bogor, Depok, Tangerang, and Bekasi. Among these hinterland cities, Depok City is growing as one of the two cities in West Java Province,

Among the various economic sectors that contribute to the Gross Regional Domestic Product of Depok City, it is found that the contribution of the creative industry sector, which is a relatively new gross regional domestic product, is already prominent. The creative industry in Depok City has started to develop since 2010 and the creative industry community since 2012. The creative industry in Depok City has also started to contribute to regional income since 2012. In 2012 - 2015, dynamically, the tertiary economic sector business group includes the sector. The creative industry contributes 46.76 percent to Depok City's gross regional domestic product, which is greater than the primary economic sector which is only 1.44 percent [2].

The dynamic growth of the city is also influenced by the environment. In a dynamic environment, several elements of governance are involved in shaping the agile process of the dynamic capabilities of city governance. Dynamic capabilities are needed by institutions or organizations to create, expand, or change primary resources intentionally and as a key to have superior performance in all types of environments, especially for highly dynamic environments [3]. Today's dynamic environment appears as a consequence of the communication and information technology revolution in all aspects of life. Turbulence in this environment indicates the complexity of the environment, which needs to be managed intelligently through dynamic capabilities supported by able people and agile processes [4].

Governance elements in development include the interaction between government, private and citizen elements related to regional development. By Osborne, governance is 
intended as a formal and informal arrangement that determines how public decisions are made, then how public actions are carried out, from the perspective of maintaining national constitutional values in the face of changes in problems, policy actors and the environment [5]. Even Neo and Chen explain the concept of governance itself in dynamic governance showing the choice of roads, policies, and structures in which the interaction of these elements encourages or otherwise hinders cooperative interactions that lead to economic progress and social welfare [4].

Therefore, within the framework of dynamic governance. there are two main levers of organizational capabilities, i.e., able people and agile processes [4]. In this article, we will raise the issue of agile processes. According to Neo and Chen, agile processes in dynamic governance are related to processes and systems in society to make decisions about the main problems and how to react to them. Therefore, the formation of Neo and Chen's agile processes is an important part (in addition to the able people element) to form dynamic capabilities so that based on an adaptive organizational culture and policies, it can become dynamic governance [4].

A dynamic governance framework is needed for today's dynamic urban areas. The environment is increasingly dynamic with the covid-19 pandemic. This is a challenge for urban areas that are seeking to explore new and potential economic sectors to increase their contribution to regional income. New and potential sectors in each region are different.

Likewise, the City of Depok, as the buffer area for the capital city of Jakarta, does not have significant potential for its natural resources. In general, the conditions of the buffer cities (hinterlands) or satellite cities around Jakarta are almost the same. This is marked by the process of changing the function of traditional agricultural land into land with social and or economic value. Data shows that there is an increase in the proportion of constructed land from 2005 to 2009 amounting to 10461.99 ha (52.23 percent) from 9,299 ha (46.49 percent) so that there is an increase of $1,162.99$ ha (5.54 percent) [6]. This condition caused the Depok City Government to take steps to raise the creative industry and accommodating it through the development of a creative economy as stated in the vision of Depok City for 2016-2021 as a city that is superior, comfortable, and religious. This vision is operationalized in the third mission of Depok City in 2016 - 2021, i.e., to develop an independent, strong, and just economy based on the creative economy [7]. Moreover, the contribution of the creative economy sector to the gross regional domestic product of Depok City increased from 2016 (14.27 percent) to 2018 by 14.55 percent [8].

The development process of the creative industry in Depok City has been dynamic since 2009, where after the formation of the creative industry community, it did not immediately move forward. Even the Department of Trade and Industry in Depok City realized that one of the problems that arose was the lack of guidance and assistance for business actors. This can be seen from the investment data for the creative industry sector in
2016 [9], which shows that in 2016 there were 8 creative industry sectors whose investment growth was below 1 percent, including: the application sector and game development $(0,34$ percent $)$, the interior design sector $(0.34$ percent $)$, the visual communication design sector ( 0.11 percent $)$ and so on. Therefore, this study explored (a) how the formation of agile processes in governance to increase the competitiveness of the creative industry in Depok City, where Depok City is one of the urban hinterland networks of the megapolitan Jakarta and (b) what is the recommended model for the formation of agile processes in governance to increase competitiveness of the creative economy industry in Depok City. The objectives of this study include: (a) to analyse governance mechanisms in the formation of agile processes to increase the competitiveness of creative industries in Depok City and (b) to develop a recommendation model for the formation of agile processes in governance to increase the competitiveness of creative industries in Depok City where the city of Depok as one of the urban hinterland networks of the megapolitan Jakarta and (b) what is the recommended model for the formation of agile processes in governance to increase the competitiveness of the industry creative in Depok City. The objectives of this study include: (a) to analyse governance mechanisms in the formation of agile processes to increase the competitiveness of creative industries in Depok City and (b) to develop a recommendation model for the formation of agile processes in governance to increase the competitiveness of creative industries in Depok City since the city of Depok as one of the urban hinterland networks of the megapolitan Jakarta and (b) what is the recommended model for the formation of agile processes in governance to increase the competitiveness of the creative industry in Depok City. The objectives of this study include: (a) to analyse governance mechanisms in the formation of agile processes to increase the competitiveness of creative industries in Depok City and (b) to develop a recommendation model for the formation of agile processes in governance to increase the competitiveness of creative industries in Depok City.

\section{RESEARCH METHOD}

To determine the formation of agile processes in governance in the development of creative industries in Depok as an urban area, qualitative methods are used, with snowball data collection techniques and interactive data analysis [10]. The data collection was conducted through in-depth interviewed with 13 key informants from 9 institutions that reflect governance elements, i.e., 6 Depok City Government work units, 1 Depok City local council agency, 2 associations of creative industry entrepreneurs and Depok City small and medium enterprises. Then field observations at the activities, situations and conditions of service activities mechanisms and the development of the competitiveness of the creative industry sector which are spread over 6 work units of the Depok City Government and their facilities. The research was conducted for 1 (one) year and 2 (two) months from August 2020 to October 2020, seeing the dynamic process of forming agile processes governance in the creative industry sector in Depok 
City. Documentation study was conducted to obtain secondary data related to the formation of agile processes in governance in the creative industry sector.

To obtain validity from field data, triangulation was carried out [11]. The type of triangulation was triangulation of data sources, both from interviewed from each element of governance the government, creative industry entrepreneurs and their associations and from city councils, literature studies and observations. Triangulation of data sources, both from interviewed from each element of governance, i.e. from the government, creative industry entrepreneurs and their associations (Depok City Creative Industry Association AIKD and Small and Medium Enterprises Association AUKM Depok City) and from city councils juxtaposed with study data literature obtained in the field, included data from the Depok City Central Bureau of Statistics in 2016 and 2018, reports on the performance of related agencies, (including the Depok City Trade and Industry Office, Office of Investment and One Stop Integrated Services (DPMPTSP) Depok City, Department of Agriculture and Fisheries Food Security, Depok City), a booklet for the investment profile of the creative industry in Depok, a profile for the creative industry in Depok City, reports from the Depok City Regional Planning Agency, and data on indicators for the creative economy of Depok City as an executive summary the Depok City Government in collaboration with the Faculty Economics and Business, University of Indonesia. These data are also juxtaposed with field observation data, in the City Government of Depok, City Council and associations of related creative industry entrepreneurs.

Interactive data analysis with condensation data flow starting from collection, selection through coding, then focusing, simplifying, abstracting, and transforming field data and secondary data. Next, perform data display for data compression again. The results of data compaction are then used for the process of verifying the conclusions where the results of the data analysis are used to formulate the agile processes model in governance in the creative industry sector of Depok City, inductively.

\section{RESULTS AND DISCUSSION}

Governance as an interaction of public decision-making following formal and informal arrangements between government, public, private. The issue of creative industries in several regions, especially urban clusters, and / or urban agglomerations in several studies shows that it will focus on the relationships formed together, the nature of clusters and networks [12]. This study also enriches insights on the creative industry in urban areas which has become a hinterland as well as a buffer zone for growth poles (in this case Jakarta as the capital of the Republic of Indonesia, as one of the poles of Indonesia's growth as a developing country). This study mainly answers how the formation of agile processes in governance, which is formed by relationships and networks in the governance system of creative industry development in Depok
City, so that it has an impact on increasing the competitiveness of its creative industry.

\section{A. Governance Mechanism in the Formation of Agile Processes in Depok City}

Initially, the discourse on governance of the development of the creative industry in Depok City was initiated by the Depok City DPRD. This shows the strength of the bargaining position and direction of governance activities, based on the political role of the Depok City Local Council, especially in Commission B in the fields of economy, finance and tourism, the Depok City Local Council.

The interaction shows a governance mechanism, considering governance is a rule of joint decision-making in which there are various kinds of actors or organizations and there is no formal supervisory system that can dictate the requirements of the relationship between these actors and organizations [13]. The following is the statement of a member of Commission B for the economy, finance and tourism of the Depok City Local Council which emphasizes that Depok City carried out creative economic development:

"The macro economy is still creative when talking about the economy, while referring to the perpetrator, i.e., the creative industry ..." (interviewed with DPRD member of Depok City Commission B, January 3, 2020).

Likewise, the city government of Depok also promotes creative economic development in its government's mission but differs in its targets and operations in related programs, because it does not specifically address creative economic development, in terms of its strategy and regulations. Although conceptually, the creative economy is more macro than the creative industry [14].

Several programs as derivatives of the goals and missions of local governments have adopted development service programs but have not been optimal. Services that are closely related to the development of creative industries are the Depok City Trade and Industry Service, Depok City Cooperatives and Micro Businesses (DKUM). develop a self-reliance, strong and equity of economy, (in the 2018 Depok City Trade and Industry Office performance report it did not completely state that the third mission based on the creative economy). The mission detailed in 2 goals related to the creative economy of the 3 existing targets, i.e., the target of increasing the capacity of small and medium industries that are creative, self-reliance and competitiveness and the goal of increasing the creative economy centre [15]. In the main performance indicators of the Depok City Trade and Industry Service, the results of the strategic goals in the form of increasing the capacity of small and medium industries were creative, independent, and competitive with the main performance indicators in the form of the percentage of creative small and medium industries in the first semester of 2019, still have not met the target, i.e. 41.25 percent of 45 percent target [15] 
However, there are efforts to improve the formation of the agile process of creative economic development carried out by the Depok City Trade and Industry Agency on the main indicators of the 2016-2021 strategic plan, on the target of increasing the capacity of innovative and competitive small and medium industries with performance indicators of the percentage of small and medium industries and the percentage of the number of certified small and medium industries. These indicators are revised to increase the capacity of creative, independent and competitive small and medium industries with a performance indicator for the percentage number of small and medium industries and independent small and medium industries. Thus, the role of government is moving towards serving than steering [16]. However, it was found that the mechanism of the role of the Depok City government with the principle of serving than steering is still not fully acceptable by the creative industry association of Depok City, as stated by the Head of Depok City DKUM:

"Every activity involves the community; the government only stimulates them to join the community. How to stimulate it by providing guidance in new entrepreneurial programs at the beginning of the year from the proposal Small and Medium Enterprises in each sub-district to new business actors"(interviewed with the Head of Depok City DKUM, January, 7, 2020).

\section{B. Agile Processes in Creative Industry Sector in Depok City}

Agile processes also involve internal organizational factors, i.e., organizational, or managerial processes (the way of things are done in the organization), structure and regulation [17]. Organizational processes have 3 roles, i.e., coordination or integration in static conditions, learning in dynamic concepts, and reconfiguration in transformational concepts (figure 1).

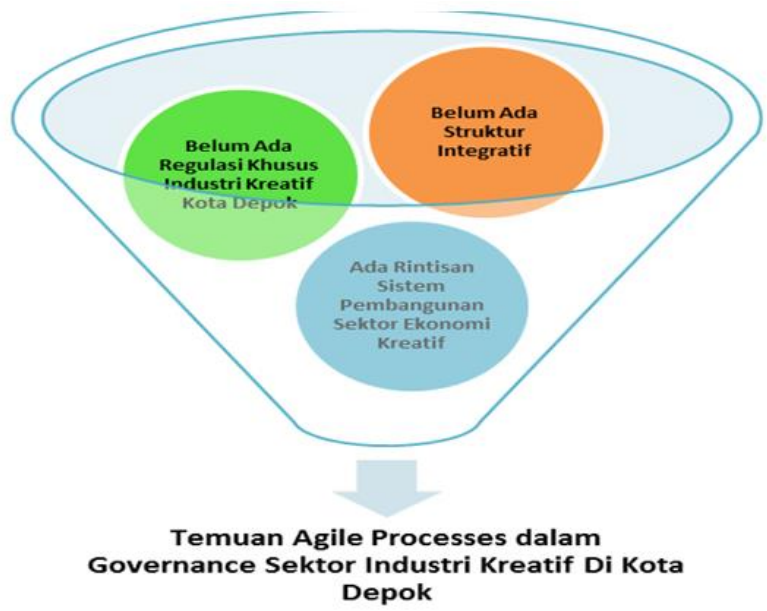

Fig. 1. Findings of agile processes in the governance of the creative industry sector in Depok City.

From the structural aspect, the creative industry sector, which is managed by the Depok City Government, does not take the form of a special unit but spreads to several agencies whose functions and roles are related to creative industry activities. The association of creative industry entrepreneurs was also formed from the Depok City Government, but not structurally under the authority of the Depok City government. The relationship is more consultative and patron-client. There are no regulations that regulate the relationship between the Depok City Government and associations and local councils related to the creative industry. The formation of creative industry agile processes found in this study is in the form of a pilot system with the vision and mission of the Depok City government which raises the issue of the creative economy, but there is no operationalization that focuses on this sector.

Even so, there have been efforts to lay the groundwork for the development of the creative industry which has been stated in the vision and mission of the Depok city government, but it has not been operationalized specifically for the creative industry, only in providing standard facilities and training for industry entrepreneurs who have access to information. This shows that the agile processes that stimulate the strengthening of dynamic capabilities for dynamic governance are still not supported by the design of a governance institutional structure to increase the competitiveness of the creative industry in Depok City. In fact, the existence of agile processes is very important to strengthen dynamic capabilities. Pezeshkan et al state that dynamic capabilities are generally positively related to competitive advantage and performance [18]

As for the types of creative industry applications and online game development (i.e., "flip.id" free interbank transfer service applications, "iGrow.asia" applications that connect investors with farmers and breeders, so they get interest-free capital, etc.) fashion and culinary, performing arts and others that fall into the creative industry category and are under the guidance of the Depok City Industry and Trade Office. There is a division of affairs in the scope of guidance for DKUM and the Depok Industry and Trade Office, Depok City:

"Creative industry under the guidance of the Industry and Trade Service. The Industry and Trade Office takes a segment of its work in the form of small businesses and above. DKUM refers more to the type of micro business with the benchmark in the form of turnover. If the turnover is 300 million and below, it is the responsibility of DKUM, while if the turnover is 300 million and above, it is the responsibility of the Industry and Trade Office. So, industry (creative) enters the Department of Industry and Trade, if specifically, there are also training such as packaging training at the Industry and Trade Service and DKUM. The two offices carry out the most programs and creative industry activities"(interviewed with members of the Depok City Senator Commission B, January 3, 2020).

However, the conditions for the development of each creative industry are not in the same dynamic, some have their investment has not grown significantly, even though almost all of them have contributed to the 2012 GRDP of Depok City [9] Even the promotion and marketing of creative industry products have not been seriously given a separate stage in the local tourism industry (i.e. the Dragon Boat Festival in Setu, Depok City), but only accompanying festival activities and 
there is no special coaching financing support at the Municipal Youth, Sports and Tourism Office Depok supervises the event, because it was not included in the scope of the main duties and functions of the Depok City Youth, Sports and Tourism Office, but from the Depok City Industry and Trade Office and or the Depok City Office of Cooperatives and Micro Businesses (DKUM). The conditions above indicate that there was no clear accommodation of guidance and services for the development of creative industries in the organizational structure of the Depok City Government. This causes the problem of a lack of internal synergy between regional devices related to development and services for the development of creative industries:

"... lack of synergy, lack of competitiveness, (limited) quantity due to human resources, infrastructure, budget ..." (interviewed with Depok City Industry and Trade Agency official, January 2, 2020).

The problem of unclear implementation of functions and fostering of creative industry development affairs in Depok City, was also emphasized by AIKD:

"The efforts are not detailed yet because there are still heads of departments who do not cover the creative industry, so they are still mixed in the structure. So, there is no special agency that oversees or handles the creative industry"(Interviewed with the Chairman of AIKD, January 8, 2020).

From the system aspect, it was found that there was no integrated creative industry development system, both upstream industries, i.e., the processing system for raw materials into finished goods for creative industries, packaging systems, quality control systems for quality products, distribution, and marketing of creative industries in a sustainable manner. The creative industry development program carried out by the Depok City Government is only on the training side, some of which are not specifically for the development of creative industries, but were related to other development programs (for example improving the quality of the family which includes community empowerment activities with the community development program for prosperous women families (P2WKS) which was carried out by the Depok City Trade and Industry Service as Depok City Industry and Trade Service officer stated:

"Usually suddenly, there are training programs that are used for fostering creative industries, coaching potential award recipients, forming industrial centre clusters, training for processing local products ... improving the quality of families, there are community empowerment activities, there is Community Development Program for Prosperous Family Women. All agencies (regional apparatus organizations) issue budgets (derived from regional revenue and expenditure budgets) and programs. One of them is that the Depok City Industry and Trade Agency is included in the program, whose activities include sewing training activities, local food processing with the aim of making the family more independent but this program changes its place every year "(interviewed with Depok City Industry and Trade Service officer, January 2, 2020).

The creative economy sector development program, which includes fostering creative industries, until early 2020, with the additional conditions of the Covid-19 pandemic, has not been able to run optimally. Although this is not solely due to the Covid-19 pandemic.

Formation agile process is constrained by the aspect of policy innovation but there was already a competitiveness training mechanism. From the regulatory aspect, it was found that there were no new and specific regulations for the sustainable creative industry, as stated of Commission B of the Depok City local council Senator:

"If the regional regulations that are used are still regional regulations on micro, small and medium enterprises in general, not specifically what is mentioned in the creative industry" (interviewed with the Local Council Depok City Commission B Senator, January 3, 2020).

This was also confirmed by Commission D Senator at the Depok City Local Council who was in Commission B for two consecutive periods:

"If the creative industry regional regulations do not exist, there are Small and Medium Enterprises Regional Regulations. It was once initiated but no one has been patented" (interviewed with the Local Council Depok City Commission D Senator, January 3, 2020).

This statement was also corroborated by the Vice Mayor of Depok City himself:

"No regulations have been issued regarding the development of the creative industry ... no regulations have been issued regarding the development of the competitiveness of the creative industries " (interviewed with Deputy Mayor of Depok, January 10, 2020).

Even, from AIKD, it was implied that specific local regulations for the creative economy or creative industry in Depok City do not yet exist and are expected to exist, as stated by the Chairman of AIKD:

"If anything is very good" (interviewed with the Chairman of AIKD, January 8, 2020).

The three elements of governance stated that there are no specific regulations related to the creative industry. Likewise, from tracing secondary data, no specific regulations for the creative economy were found. Meanwhile, the regulation used to regulate the creative industry is the Depok City Regulation No.18 of 2012 concerning Small and Medium Enterprises, meaning that there has not been any local industry or economy creative regulation innovation formulated and implemented by the Depok City Government and the Depok City DPRD, which underlie the development of the creative industry sector.

From the aspect of competitiveness training mechanisms, various trainings have been carried out, but they have not been optimal in open access to all creative industry entrepreneurs, 
without denying the existence of good relations between the Depok City Government and the existing associations of creative industry entrepreneurs and Micro, Small and Medium Enterprises.

From the aspect of the Depok City Government, the establishment of the agile process for the development of the creative industry sector is constrained by the limited accommodation of planning policies, infrastructure, intensity, socialization, and control of planning and cross-sectoral coordination activities. This was stated by a source for the Depok City Regional Planning and Development Agency, i.e.:

“... We (the Regional Planning and Development Agency) are on the planning side. So, if the Regional Planning and Development Agency is more concerned with how we try to structure this creative economy so that it grows ... We only serve as suggestions or input. We only got that far and did not reach a certain intervention ... the creative economy is developing very fast. That is what makes it difficult for us (the City Government of Depok) to follow... (training facilities and infrastructure) internal resources are indeed needed, because it is felt that they are still lacking to oversee development because they are still new because there is no institutional yet. Depok City Regional Development) yes, it is a little difficult to synchronize between sectors"(interviewed with the Depok City Regional Planning and Development Agency Officer, January,3,2020).

In terms of industry entrepreneurs, access, development funds, association member responsiveness and training sustainability are constrained. This was conveyed by the Chairman of the Depok City Small and Medium Enterprises Association:

"There is not even access to training information and requires training or curation, benchmark products of a kind to motivate product development" (interviewed with the Chairman of the Depok City Small and Medium Enterprises Association, April,19 2020).

From the explanation of the Depok City Government and the Depok City Small and Medium Business Association, it shows that the formation of agile processes from networks and relationships formed together by elements of governance still requires a fundamental collaboration system for the long term, because the networks and relationships formed are still patronclient between the Depok City Government and AIKD and AUKM Depok City. This clearly does not illustrate what Scott (2000) stated that the survival and growth of the creative industry is generally based on a mixture of institutional support, public or private partnerships and training institutions [19].

On the other hand, apart from some problems the establishment of agile processes in the development of the creative industry sector in Depok City, there is an element that strengthen the formation of natural agile processes. This element is related to human relations and the role of leadership, i.e., collaboration between the government and associations of creative industry entrepreneurs, as stated by the Chair of AIKD:

"Their activities (Department of Industry and Trade) are in synergy with the creative industry in Depok, incidentally we (AIKD) are a direct association under the guidance of the Industry and Trade Office" (interviewed with the Chairman of AIKD, January 8, 2020).

\section{Recommended Model}

The finding of elements of network collaboration between the government and associations of creative industry entrepreneurs and associations of Micro, Small and Medium Enterprises, constructs the formation of agile processes for the development of creative industries in Depok City from previously related to 3 elements consisting of structure, system, and regulation into 4 elements, i.e., structure, systems, regulations and collaborative networks of governments and associations (figure 2).

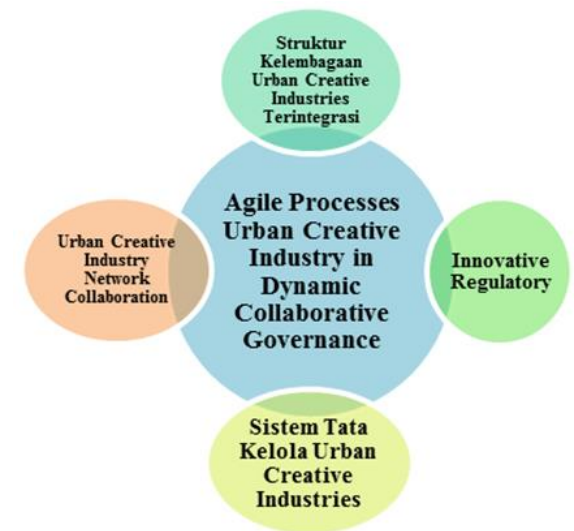

Fig. 2. Recommendation model agile processes urban creative industry in dynamic collaborative governance.

There is still a tendency for collaboration between the government and associations of creative industry entrepreneurs and Micro, Small and Medium Enterprises (both of which intersect in the creative industry), and the Depok City Government is still patron-client, as stated by the Chair of the Small and Medium Enterprises Association (AUKM) Depok City:

"... what (the association) wants is a special budget for the creative industry ... We (the association) also have limitations but there is no tactical supply or funds to be able to increase promotion and marketing at national or international events" (interviewed with the Chairman of AUKM Depok City, January 8, 2020).

Collaboration is a process of transformation that is broader than just coordination and cooperation. This is because collaboration is a process that brings public values into the governance process, even collaboration is defined as a creative process that is jointly mediated by autonomous institutions [20]. This is certainly the work of governance in shaping the 
dynamic agile processes of the creative industry in Depok City. Lessons from Australia about network governance that link collaboration between government, companies and communities need to be used as valuable lessons from the benefits of collaboration [21]. However, it is still necessary to be vigilant of the idea of homogenization in structuring the creative industry and its regulation which it is necessary to understand the dynamic space and uniqueness of each creative industry actors or entrepreneurs so that they cannot be treated homogeneously. This refers to the case of the Krowji creative cluster in West Cornwall, UK which was studied by Harvey [12].

\section{CONCLUSION}

The conclusion from this research is that the governance mechanism in the formation of agile processes to increase the competitiveness of the creative industry in Depok City is still semi-technocratic. The current formation of agile processes was still lacking a number of problems. The first problem was access to communication between related governance institutions has not yet fully open. The second problem was that there has no integrated creative industry institutional structure design even though the coordination of development designs among stakeholders has been carried out so that the agile process has not been fully established. In the establishment of the dynamic ability agile process at the local level, it was found that the role of the collaborative network of local governments. The recommendation model for the establishment of agile processes in governance to increase the competitiveness of the creative industry in Depok City must be positioning a strong institutional collaboration that regulates the creative industry so that it would be a dynamic collaborative agile process model for local government. The theoretical implication of agile process for the dynamic capabilities of local governments for the development of creative industries is the need for an accommodative policy framework theory for innovative urban creative industry regulations which flexible to the diversity (entrepreneurs) of dynamic creative industries, accompanied by dynamic integrative structural designs and an inventory of local cultures in local creative industry development.

\section{REFERENCES}

[1] Book II of the National Medium Term Development Plan of the Republic of Indonesia 2015-2019, pp. 8-11, 2015.
[2] Depok City Central Bureau of Statistics, Depok City in Figures 2016 Depok: BPS Depok City, 2016.

[3] D. Teece, "The foundations of enterprise performance: Dynamic and ordinary capabilities in an (economic) theory of firms," The Academy of Management Perspectives, vol. 28, no. (4), pp. 328-352, 2014

[4] B.S. Neo and G. Chen, Dynamic governance: Embedding culture capabilities and change in Singapore (English version). World Scientific, 2007.

[5] S.P. Osborne, The New Public Governence? Emerging perspectives on the theory and practice of public governance. New York: Routledge 2010 .

[6] Depok City Regional Planning and Development Agency, Depok City Community Satisfaction Index (IKM) Study, 2012.

[7] Depok City Industry and Trade Office, Revised Strategic Plan of Depok City Industry and Trade Service. Depok City: Depok City Industry and Trade Office, 2017.

[8] Diskominfo Depok City - FEB UI, Depok Creative Economy Indicator 2018 .

[9] BPMP2T Depok, 2016 Depok City Creative Industry Sector Investment Profile. Depok: BPM2T, 2016.

[10] M.B. Miles, A.M. Huberman and J. Saldana, Qualitative data analysis: A methods sourcebook. USA: Sage Publication, 2014.

[11] L.W. Neuman, Social Research Methods Qualitative and Quantitative Approaches. Essex: Pearson, 2014.

[12] D.C. Harvey, H. Hawkins and N.J. Thomas, "Thinking creative cluster beyond the city: People, places and networks," Geoforum, vol. 43, no. (3), pp. 529-539, 2012.

[13] C. Vasudha and G. Stoker, "Governance Theory and Practice: A CrossDisciplinary Approach," Journal of Public Administration, vol. 87, no. (4), pp. 982-983, 2009.

[14] J. Howkins, Creative Economy: how people make money from ideas Penguin Group (USA). J. Howkins Incorporated. Allen Lane, 2001.

[15] Depok City Industry and Trade Office, Report of SAKIP in the Contex of Implementing SAKIP of the 2018 City of Depok City of Trade and Industry. Depok City Government, 2019.

[16] J.V. Denhardt and R. Denhardt, The New Public Service: Serving, Not Steering. New York: Routledge, 2007.

[17] D.J. Teece, Technological know-how, organizational capabilities, and strategic management: business strategy and enterprise development in competitive environments. World Scientific, 2008.

[18] A. Pezeshkan, S. Fainshmidt, A. Nair, M.L. Frazier and E. Markowski, "An empirical assessment of the dynamic capabilities-performance relationship," Journal of Business Research, vol. 69, no. (8), pp. 29502956, 2016

[19] A. Scott, The Cultural Economy of Cities. London: Sage, 2000

[20] J. O'Flynn and J. Wanna, Collaborative Governance: A new era of public policy in Australia? ANU Press, 2008

[21] E. Henry, Perspectives of community organizations: The Smith Family Experience. Canberra: ANU E Press, 2008. 